\title{
PROFIL EVALUASI MODEL KIRKPATRIK PADA PELATIHAN PENYUSUNAN LAPORAN KEUANGAN SYARIAH BAGI PENGURUS KOPERASI
}

\author{
ELOK NING FAIKOH \\ UPT Pelatihan Koperasi dan UKM Provinsi Jawa Timur \\ Email : $\underline{\text { elok090988@gmail.com }}$
}

\begin{abstract}
ABSTRAK
Penelitian ini bertujuan untuk mendapatkan gambaran tentang evaluasi model Kirkpatrik level 1 dan 2 pada pelaksanaan Pelatihan Penyusunan Laporan Keuangan Syariah bagi Pengurus Koperasi. Metode penelitian yang digunakan adalah deskriptif kuantitatif. Penelitian ini mengambil populasi peserta Pelatihan Penyusunan Laporan Keuangan bagi Pengurus Koperasi di Kabupaten Pasuruan yang di laksanakan oleh UPT Pelatihan Koperasi dan UKM Provinsi Jawa Timur sejumlah 30 orang. Evaluasi level 1 (reaksi) dalam penelitian ini didapat dengan melakukan pengisian kuisioner dengan skala Likert 1 (satu) sampai 5 (lima) dan evaluasi level 2 (pembelajaran) diperoleh dengan melakukan pre-test pada awal dan post- tes dan akhir pelatihan. Hasil evaluasi Kirkpatrik level 1 (reaksi) mengambarkan kepuasan (reaksi positif) dari peserta terhadap pelaksanaan pelatihan. Sedangkan hasil dari evaluasi level 2 (pembelajaran), terjadi peningkatan pengetahuan tentang materi penyusunan laporan keuangan bagi pengurus koperasi. Adanya peningkatan nilai post-test menunjukkan adanya peningkatan pengetahuan dan skill dari peserta pelatihan dan merupakan keberhasilan dari proses pembelajaran
\end{abstract}

Kata Kunci : Evaluasi pelatihan, model kirkpatrik, pelatihan Penyusunan, Laporan Keuangan

\section{ABSTRACT}

This study aims to obtain an overview of the evaluation of the Kirkpatrik model level 1 and 2 in the implementation of the Sharia Financial Report Preparation Training for Cooperative Management. The research method used is descriptive quantitative. This study took a population of 30 participants of the Financial Report Preparation Training for Cooperative Management in Pasuruan Regency which was carried out by the East Java Province Cooperative and SME Training UPT. Level 1 evaluation (reaction) in this study was obtained by filling out a questionnaire with a Likert scale of 1 (one) to 5 (five) and level 2 evaluation (learning) was obtained by conducting pre-test at the beginning and post-test and at the end of the training. The results of the Kirkpatrik level 1 evaluation (reaction) describe the satisfaction (positive reaction) of the participants towards the implementation of the training. While the results of the level 2 evaluation (learning), there was an increase in knowledge about the material for preparing financial reports for cooperative management. An increase in post-test scores indicates an increase in the knowledge and skills of the trainees and is the success of the learning process

Keywords: Training evaluation, kirkpatrik model, Preparation training, Financial Report

\section{PENDAHULUAN}

Laporan keuangan merupakan salah satu sumber informasi yang sangat penting untuk menilai hasil pengelolaan koperasi, disamping sebagai alat pertanggungjawaban pengurus kepada anggotanya. Tujuan laporan keuangan bagi koperasi menurut Arifin (2009) antara lain: 1) mengetahui seberapa besar manfaat yang diperoleh anggota, 2) mengetahui keberhasilan pengelolaan keuangan koperasi dalam satu periode dilihat dari jumlah SHU yang diperoleh, 3) mengetahui aset, kewajiban dan modal yang dimiliki koperasi dengan memisahkan antara yang berkaitan dengan anggota dan bukan anggota 4) mengetahui transaksi dan kejadian yang dapat merubah aset,kewajiban, dan modal yang dimiliki koperasi. 
Laporan keuangan koperasi harus disusun berdasarkan standar dan prinsip yang berlaku agar dapat dipertanggungjawabkan kredibilitasnya. Untuk laporan keuangan pada koperasi dengan prinsip syariah, selain mengacu pada SAK ETAP juga harus berpedoman pada Peraturan Menteri Koperasi, Usaha Kecil dan Menengah RI Nomor 14 tahun 2015. Namun, permasalahan yang terjadi di lapangan, hanya sedikit koperasi yang mampu menyusun laporan keuangan sesuai dengan standar dan peraturan yang berlaku. Atas dasar permasalhan inilah, maka UPT Pelatihan Koperasi dan UKM Provinsi Jawa Timur pada tanggal 08 s.d 10 September 2021 menyelenggarakan pelatihan bagi Koperasi/UMKM/Kelompok strategis dengan tema "Pelatihan Penyusunan Laporan Keuangan Bagi Pengelola Koperasi di Kabupaten Pasuruan". Pelatihan yang didanai oleh Dana Alokasi Non Fisik tahun anggaran 2021 ini dilaksanakan di Valensia Bakery Café \& Resto Kota Pasuruan. dengan menjaga protokol kesehatan yang ketat.

Menurut Aditama (2020), dalam manajemen terdapat beberapa fungsi pokok yaitu perencanaan, pengorganisasian, pelaksanaan dan pengendalian. Fungsi Pengendalian adalah bentuk evaluasi yang selalu harus dilakukan dan telah menjadi bagian tak terpisahkan dari suatu upaya apapun yang terprogram dan tersistematis, tak terkecuali program pelatihan. Sebagai sebuah program, efektifitas dan kemanfaatan dari suatu pelatihan akan dapat diketahui jika pada akhir kegiatan dilakukan sebuah evaluasi. Hal ini juga sesuai dengan Peraturan Menteri Koperasi dan UKM RI No.18 tahun 2015, Pasal 1 yang berbunyi "Evaluasi adalah kegiatan penilaian terhadap suatu pelaksanaan pendidikan dan pelatihan setelah seluruh kegiatan selesai dilaksanakan, sehingga diketahui manfaat dan dampaknya”.

Salah satu metode yang umum digunakan untuk melakukan evaluasi pelatihan adalah Kirkpatrick Anlysis. Metode ini merupakan model yang dikembangkan pertama kali oleh Daniel L.Kirkpatrick pada tahun 1959. Menurut Kirkpatrick (2006) Ada empat tingkatan evaluasi dalam model evaluasi pelatihan. Pertama, evaluasi level 1 (rekasi) yaitu evaluasi untuk mengukur reaksi kepuasan peserta terhadap pelaksanaan pelatihan. Kedua, evaluasi level 2 (pembelajaran) yaitu evaluasi untuk mengukur sejauh mana peserta memahami materi yang diberikan. Ketiga, evaluasi level 3 (tingkah laku) yaitu evaluasi untuk mengukur sejauhmana peserta menerapkan pemahaman kompetensi yang diperoleh dalam lingkungan pekerjaannya. Keempat, evaluasi level 4 (hasil) yaitu evaluasi untuk mengukur seberapa besar dampak pelaksanaan pelatihan terhadap kinerja pekerjaan ataupun hasil akhir yang diharapkan.

Penelitian ini bertujuan untuk mengetahui hasil evaluasi Pelatihan Penyusunan Laporan Keuangan Syariah bagi Pengurus Koperasi di Kabupaten Pasuruan di tinjau dari evaluasi model Kirkpatrick level 1 (reaksi) dan level 2 (pembelajaran). Hasil penelitian ini diharapkan dapat memberikan manfaat bagi penyelenggara pelatihan sebagai bahan pertimbangan untuk memperbaiki kinerja pelaksanaan pelatihan kedepan melalui pengurangan atau penghilangan faktor penghambat. Selain itu juga diharapkan dapat memberikan informasi kuantitatif kepada fasilitator (trainer) yang bisa digunakan untuk dasar pembuatan standar pengajaran pada program pelatihan selanjutnya.

\section{METODE PENELITIAN}

Penelitian ini menggunkaan metode deskriptif kuantitatif dengan tujuan menggambarkan hasil pelatihan yang tinjau dari evaluasi model Kirkpatrick level 1 (reaksi) dan level 2 (pembelajaran). Evaluasi level 1 (reaksi) dalam penelitian ini dilakukan dengan mengukur reaksi terhadap beberapa aspek, yaitu materi, fasilitator, waktu pelaksanaan, konsumsi, serta sarana dan prasarana. Teknik pengambilan data menggunakan kuisioner dengan skala Likert 1 (satu) sampai 5 (lima). Untuk evaluasi level 2 (pembelajaran), aspek yang diukur adalah pemahaman peserta terhadap materi yang diberikan saat pelatihan. Untuk itu, dirancang sejumlah pertanyaan dan diberikan kepada peserta pada saat sebelum pelatihan (pretest) dan sesudah pelatihan (post-test). Hasil dari pre-test dan post-test kemudian ditabulasi dan dibandingkan untuk mengetahui peningkatan nilainya. Objek dalam penelitian ini adalah peserta Pelatihan Penyusunan Laporan Keuangan bagi Pengurus Koperasi di Kabupaten 
Pasuruan yang di Laksanakan oleh UPT Pelatihan Koperasi dan UKM Provinsi Jawa Timur pada tanggal 08 s.d 10 September 2021 sejumlah 30 orang.

\section{HASIL DAN PEMBAHASAN}

\section{A. Hasil}

\section{- $\quad$ Evaluasi Level 1 (Reaksi)}

Evaluasi level 1 dilakukan terhadap reaksi peserta pelatihan yang bertujuan untuk mengukur kepuasan peserta (customer satisfaction). Beberapa aspek yang dikaji meliputi materi diberikan, fasilitator (narasumber/ widyaiswara), waktu pelaksanaan, konsumsi, serta sarana dan prasarana.

Gambaran tingkat kepuasan peserta terhadap proses pelatihan, khususnya terkait dengan materi yang diberikan dapat dilihat pada Gambar 1. Dari hasil yang diperoleh, maka dapat dikatakan bahwa seluruh peserta menyatakan reaksi positif terhadap materi yang diberikan. 56,67\% peserta menyatakan materi yang diberikan sangat baik. Sisanya menyatakan baik dan cukup baik. Beberapa pertanyaan yang diajukan terkait aspek ini yaitu kesesuaian materi dengan kebutuhan peserta, dukungan materi terhadap tugas peserta di koperasi, dan kemanfaatan materi yang diberikan secara keseluruhan.

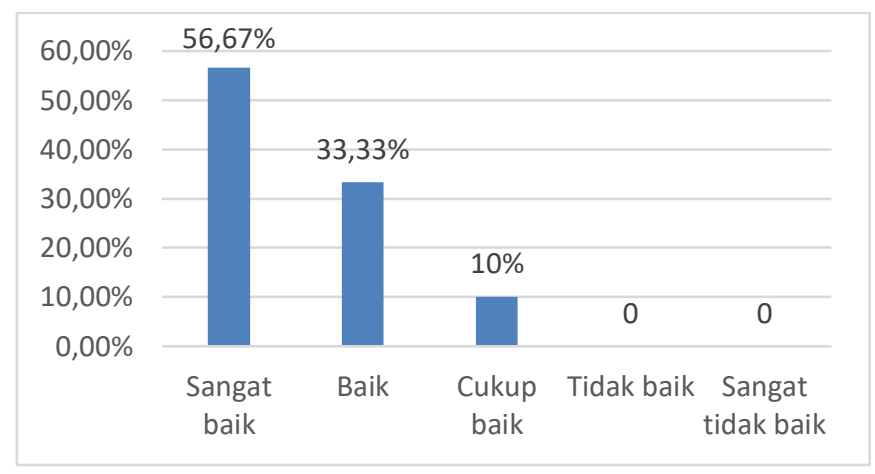

\section{Gambar 1. Reaksi Peserta Terhadap Materi}

Adapun gambaran tingkat kepuasan peserta terhadap proses pelatihan, khususnya pada aspek penilaian terhadap fasilitator dapat dilihat pada Gambar 2. Dari hasil yang diperoleh, maka dapat dikatakan bahwa seluruh peserta menyatakan reaksi positif terhadap fasilitator. Penilaian terhadap cara penyampaian materi oleh fasilitator serta penguasaan materi oleh fasilitator dinilai sangat baik oleh 53,33\% peserta, sisanya menyatakan baik dan cukup baik.

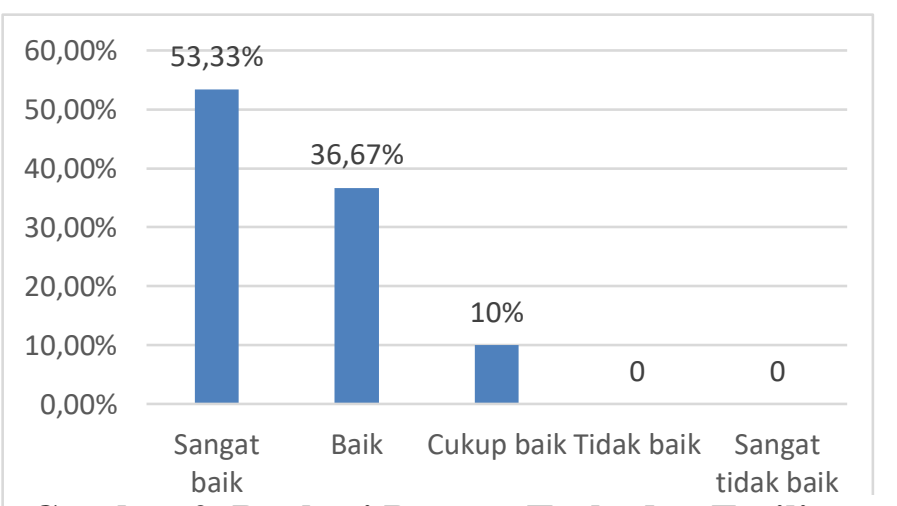

Gambar 2. Reakasi Peserta Terhadap Fasilitator

Aspek berikutnya yang dinilai adalah waktu yang digunakan untuk pelaksanaan pelatihan. Gambaran tingkat kepuasan peserta terhadap waktu yang digunakan untuk pelaksanaan pelatihan dapat dilihat pada Gambar 3. Dari hasil yang di dapat, menggambarkan bahwa seluruh peserta bereaksi positif terhadap waktu yang digunakan untuk pelaksanaan 
pelatihan. Waktu yang digunakan yaitu selama 3 (tiga) dinilai baik oleh $50 \%$ peserta. Sedangkan $40 \%$ peserta menyatakan sangat baik dan sisana menyatakan cukup baik.

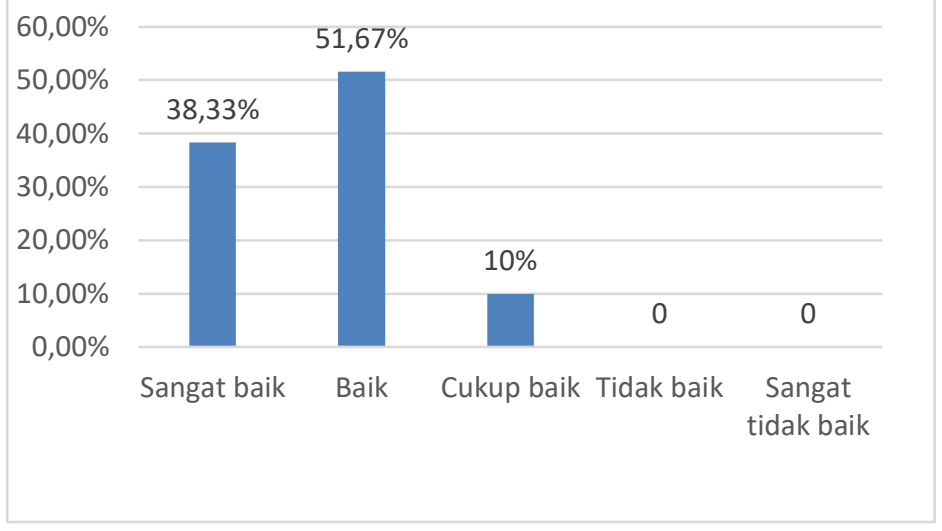

\section{Gambar 3. Reaksi Peserta Terhadap Waktu Penyelenggaraan Pelatihan}

Adapun gambaran tingkat kepuasan peserta terhadap aspek konsumsi yang disajikan selama pelatihan dapat dilihat dari Gambar 4. Dari hasil yang diperoleh, diketahui bahwa seluruh perserta bereaksi positif terhadap konsumsi yang disajikan selama pelatihan berlangsung. Variasi menu makanan dan kebersihan makanan dinilai baik oleh 51,67\% peserta, sisanya sebanyak $38,33 \%$ menyatakan sangat baik, dan $10 \%$ menyatakan cukup baik.

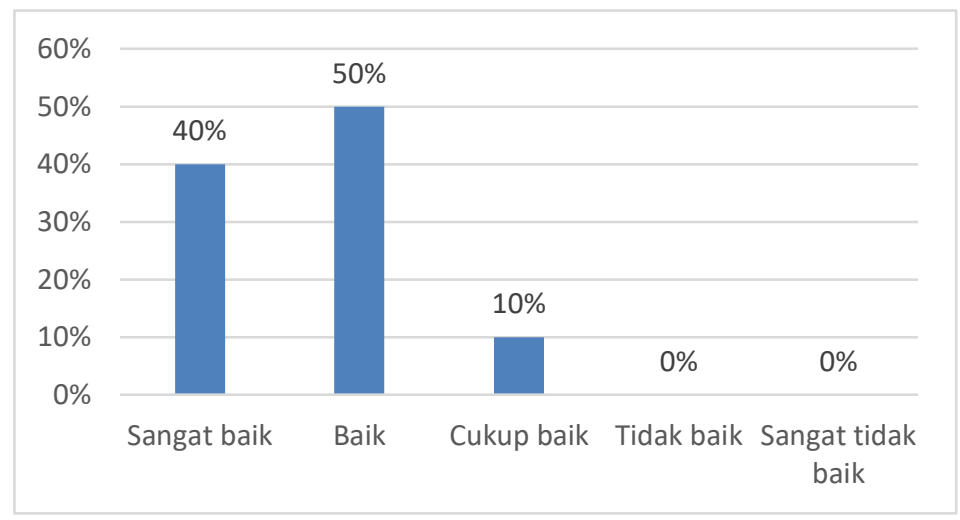

\section{Gambar 4. Reaksi Peserta Terhadap Konsumsi yang Disajikan}

Aspek terakhir yang dinilai adalah sarana dan prasarana. Gambaran tingkat kepuasan terhadap sarana dan prasarana pelatihan dapat dilihat pada Gambar 5. Dari hasil yang diperoleh, dapat diketahui bahwa sebagian besar peserta bereaksi positif terhadap sarana dan prasarana pelatihan. Sebanyak 53,33\% peserta menyatakan baik terhadap kebersihan ruangan, alat bantu pelatihan (lcd proyektor dan papan tulis) serta bahan serahan (Atk dan modul). Sebanyak $38,89 \%$ menyatakan sangat baik dan $6,67 \%$ menyatakan cukup baik. Sedangkan ada $1,11 \%$ peserta yang menyatakan sangat tidak baik. 
Vol 1. No 2. November 2021, e-ISSN : 2807-1808 | P-ISSN : 2807-2294

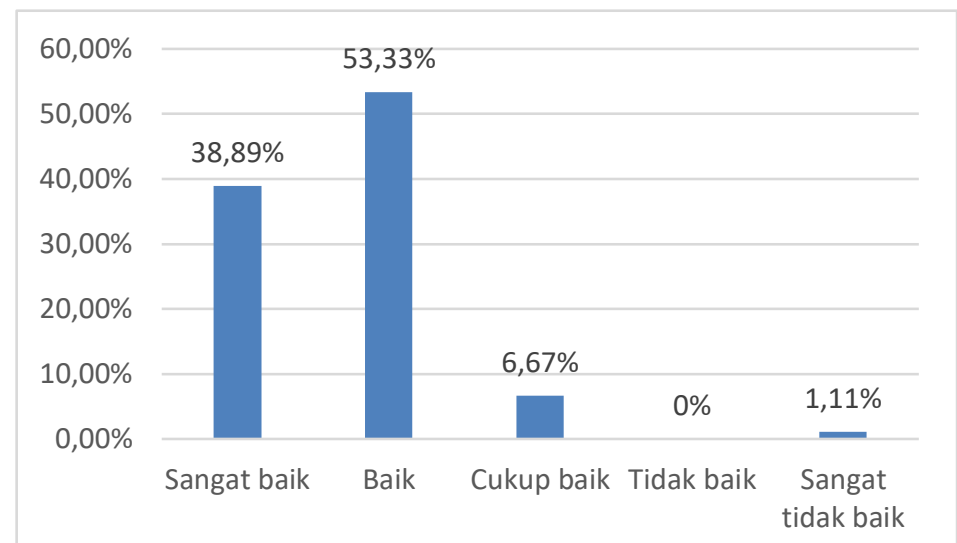

\section{Gambar 5. tingkat kepuasan terhadap sarana dan prasarana pelatihan}

Jika digambarkan secara keseluruhan, maka rata-rata penilaian peserta terhadap kelima aspek dengan skala penilaian 1-5, dapat dilihat pada Gambar 6. Dari data tersebut, dapat digambarkan bahwa peserta bereaksi positif terhadap pelaksanaan pelatihan secara keseluruhan. Penilaian peserta berkisar antara 4,2 hingga 4,6, yang artinya pelatihan telah dilaksanakan dengan baik dilihat dari aspek materi yang diberikan, fasilitator, waktu pelaksanaan, komsumsi yang disajikan serta sarana dan prasarana yang disediakan oleh panitia.

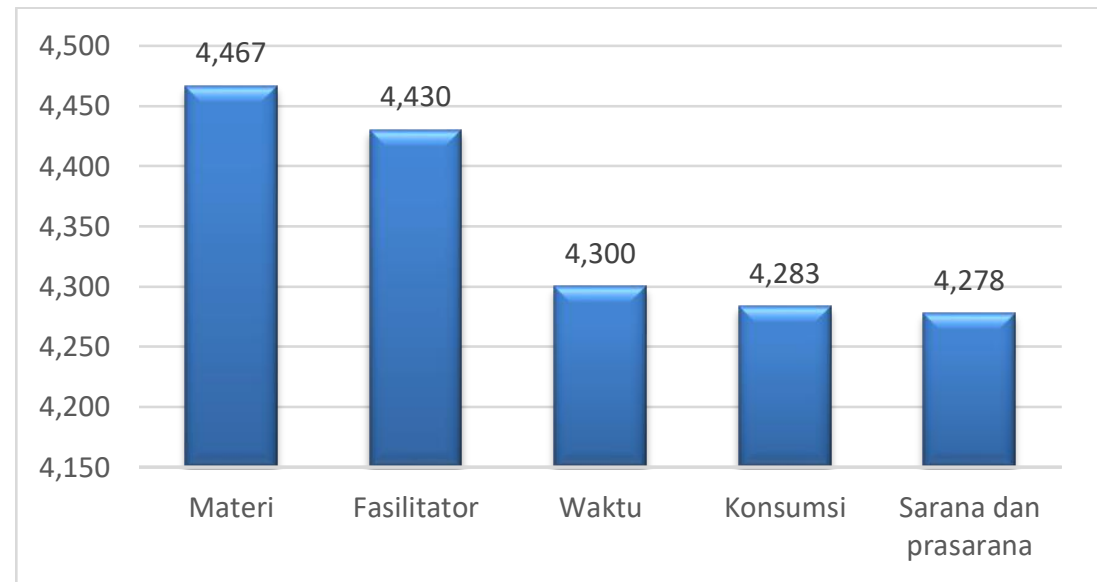

Gambar 6. Reaksi Peserta Terhadap Keseluruhan Pelatihan

- $\quad$ Evaluasi Level 2 (Pembelajaran)

Penilaian evaluasi level 2 (pembelajaran) ini lebih mengarah pada penilain hasil (output). Evaluasi ini dilakukan untuk mengetahui penguasaan terhadap materi yang diberikan selama pelatihan. Hasil pre-test dan post-test dapat dilihat pada Tabel 1.

Table 1. Nilai Pre- Test dan Post- Test Peserta Pelatihan

\begin{tabular}{cccc}
\hline Peserta ke- & $\begin{array}{c}\text { Nilai Pre } \\
\text { Test }\end{array}$ & $\begin{array}{c}\text { Nilai Post } \\
\text { Test }\end{array}$ & Peningkatan \\
\hline $\mathbf{1}$ & 70,00 & 76,67 & 6,67 \\
\hline $\mathbf{2}$ & 43,33 & 80,00 & 36,67 \\
\hline $\mathbf{3}$ & 50,00 & 80,00 & 30,00 \\
\hline $\mathbf{4}$ & 63,33 & 86,67 & 23,34 \\
\hline $\mathbf{5}$ & 40,00 & 50,00 & 10,00 \\
\hline $\mathbf{6}$ & 43,33 & 70,00 & 26,67 \\
\hline
\end{tabular}


Vol 1. No 2. November 2021, e-ISSN : 2807-1808 | P-ISSN : 2807-2294

\begin{tabular}{cccc}
\hline $\mathbf{7}$ & 50,00 & 63,33 & 13,33 \\
\hline $\mathbf{8}$ & 33,33 & 43,33 & 10,00 \\
\hline $\mathbf{9}$ & 26,67 & 33,33 & 6,66 \\
\hline $\mathbf{1 0}$ & 26,67 & 33,33 & 6,66 \\
\hline $\mathbf{1 1}$ & 50,00 & 56,67 & 6,67 \\
\hline $\mathbf{1 2}$ & 73,33 & 80,00 & 6,67 \\
\hline $\mathbf{1 3}$ & 70,00 & 80,00 & 10,00 \\
\hline $\mathbf{1 4}$ & 56,67 & 83,33 & 26,66 \\
\hline $\mathbf{1 5}$ & 50,00 & 50,00 & 0,00 \\
\hline $\mathbf{1 6}$ & 50,00 & 46,67 & $-3,33$ \\
\hline $\mathbf{1 7}$ & 40,00 & 73,33 & 33,33 \\
\hline $\mathbf{1 8}$ & 36,67 & 73,33 & 36,66 \\
\hline $\mathbf{1 9}$ & 36,67 & 56,67 & 20,00 \\
\hline $\mathbf{2 0}$ & 20,00 & 53,33 & 33,33 \\
\hline $\mathbf{2 1}$ & 36,67 & 60,00 & 23,33 \\
\hline $\mathbf{2 2}$ & 30,00 & 63,33 & 33,33 \\
\hline $\mathbf{2 3}$ & 36,66 & 70,00 & 33,34 \\
\hline $\mathbf{2 4}$ & 70,00 & 80,00 & 10,00 \\
\hline $\mathbf{2 5}$ & 70,00 & 80,00 & 10,00 \\
\hline $\mathbf{2 6}$ & 50,00 & 76,67 & 26,67 \\
\hline $\mathbf{2 7}$ & 63,33 & 76,67 & 13,34 \\
\hline $\mathbf{2 8}$ & 33,33 & 53,33 & 20,00 \\
\hline $\mathbf{2 9}$ & 26,67 & 73,33 & 46,66 \\
\hline $\mathbf{3 0}$ & 50,00 & 66,67 & 16,67 \\
\hline & & & \\
\hline
\end{tabular}

\section{B. Pembahasan}

Evaluasi Kirkpatrik level 1 (reaksi) mengambarkan kepuasan peserta terhadap pelaksanaan pelatihan. Hal ini juga menggambarkan motivasi belajar dari peserta. Menurut Kirkpatrick (2006), ada beberapa alasan pentingnya mengetahui reaksi peserta terhadap suatu proses pelatihan, yaitu 1) memberikan umpan balik yang berharga yang dapat membantu mengevaluasi program serta kritik dan saran untuk peningkatan program pelatihan selanjutnya 2) memberikan umpan balik terhadap fasilitator (trainer) tentang efektifitas mereka saat mengajar 3) memberikan informasi kuantitatif kepada para pembuat keputusan terkait dengan pelaksanaan program pelatihan, serta 4) memberikan informasi kuantitatif kepada fasilitator (trainer) yang bisa digunakan untuk dasar pembuatan standar pengajaran di pada program pelatihan selanjutnya.

Dari semua aspek yang dinilai, rata-rata memberikan reaksi yang positif. Dengan kata lain, peserta merasa puas dengan pelaksanaan pelatihan secara keseluruhan. Hal ini sesuai dengan yang dikemukakan oleh Basir (2013) bahwa kualitas pelaksanaan suatu pelatihan dapat diukur melalui tingkat kepuasan pesertanya. Keduanya berbanding lurus. Semakin bagus pelaksanaan suatu pelatihan akan semakin bagus pula respon kepuasan peserta terhadap penyelenggaraan pelatihan tersebut.

Dari segi materi yang diberikan, peserta merasa sangat puas dengan memberi nilai sangat baik (nilai 4,5). Materi yang disampaikan sudah sesuai dengan tujuan pelatihan, serta bermanfaat dan cukup membantu pekerjaan mereka. Pelatihan penyusunan laporan keuangan ini berfokus pada penyusunan laporan keuangan bagi Koperasi Simpan Pinjam dan Pembiayaan Syariah (KSPPS), sehingga materi yang diberikan cukup komperhensif mulai dari Akuntansi Dasar Koperasi, Akuntansi Syariah untuk KSPPS, hingga Analisa Rasio Keuangan. Materi 
tambahan pendukung juga diberikan dalam porsi kecil seperti akses pembiayaan dan izin usaha koperasi.

Sedangkan dari aspek fasilitator, peserta merasa puas dengan memberi penilaian baik $(4,3)$. Fasilitaror yang berasal dari Lembaga Pendidikan Sidogiri dinilai telah sesuai dengan materi yang dibawakan. Penguasaan materi dan cara penyampaian yang baik, membuat materi yang kompleks dapat tersampaikan dengan lebih sederhana. Dengan menggunakan media pembelajaran seperti power point yang yang menarik serta mudah dipahami, membuat peserta antusias dan tidak merasa bosan. Namun demikian, fasilitator tetap perlu melakukan update kompetensi dan pengetahuan serta mengembangkan metode pembelajaran untuk meningkatkan kepuasan peserta pada proses pembelajaran di masa yang akan datang.

Adapun penilaian terhadap waktu pelaksanaan yang berdurasi 3 (hari) mendapat nilai baik $(4,3)$. Jangka waktu pelatihan dapat disesuaikan dengan jam pelajaran yang dibutuhkan serta anggaran yang tersedia. Pemanfaatan waktu yang optimal dengan memulai acara tepat waktu dan meminimalisir keterlambatan kehadiran peserta harus dilakukan sehingga pelatihan berlangsung secara efektif.

Penilaian dari segi konsumsi yang disajikan serta sarana dan prasarana yang disediakan masing-masing mendapat penilaian baik $(4,2)$. Menu makanan yang disajikan bervariasi yang terdiri dari menu makanan utama serta makanan ringan. Makanan dan peralatan makan juga terjaga kebersihannya. Peserta juga memberikan nilai baik terhadap kebersihan ruangan, alat bantu pelatihan (lcd proyektor dan papan tulis) serta bahan serahan (Atk dan modul) yang diterima. Seperti yang dinyatakan oleh Aulia (2020) bahwa ketersedian fasilitas dalam proses pembelajaran adalah sesuatu yang mutlak diperlukan karena fasilitas yang lengkap akan menambah perhatian, semangat serta peningkatan motivasi dalam sebuah kegiatan pembelajaran.

Evaluasi Kirkpatrik level 2 (pembelajaran) adalah mengukur efektivitas program pembelajaran (Evaluating Learning) yang berkaitan dengan tiga aspek yaitu peningkatan pengetahuan, perbaikan keterampilan dan perubahan sikap pada peserta. Proses pembelajaran akan dianggap gagal jika pada ketiga aspek tersebut tidak terlaksana atau tidak terjadi perubahan. Penilaian evaluating learning lebih mengarah pada penilaian hasil belajar (output).

Dari hasil evaluasi level 2 ini menggambarkan bahwa peserta mengalami peningkatan pemahaman secara signifikan. Dari total 30 peserta, 29 peserta mengalami peningkatan pemahaman materi. Sedangkan 1 orang peserta mengalami penurunan pemahaman materi pelatihan. Nilai rata-rata pre-test dari 30 peserta adalah 46,57 dan nilai rata-rata post-test adalah 65,67. Dengan demikian terjadi peningkatan pengetahuan tentang materi penyusunan laporan keuangan bagi koperasi. Peningkatan yang didapat bervariasi dari 6,67 poin hingga 46,66 poin. Jika diambil rata-rata peningkatan pengetahuan atau penambahan nilai adalah 19,11 poin. Adanya peningkatan nilai post-test menunjukkan adanya peningkatan pengetahuan dan skill dari peserta pelatihan dan menggambarkan terjadinyaproses belajar yang efektif. Hasil ini didukung dengan teori yang dikemukakan oleh Kirkpatrik (2006) bahwa peserta pelatihan dikatakan telah belajar apabila pada dirinya telah mengalami peningkatan pengetahuan, sebagai salah satu dari tiga aspek yang ditingkatkan oleh pelatihan (peningkatan pengetahuan, perbaikan keterampilan, dan perubahan sikap).

Meskipun demikian, masih terdapat perbedaan nilai yang mencolok yang di dapat oleh peserta. Nilai pre-test tertinggi yaitu 73,33 dan terendah adalah 20. Sedangkan nilai dari posttest tertinggi adalah 86,67 dan terendah adalah 33,33. Hal ini dapat terjadi karena tingkat pemahan awal peserta yang bervariasi. Penyebabnya bermacam-macam, mulai dari latar belakang pendidikan yang bervariasi, jenis koperasi, serta jabatan di koperasi. Dari fakta ini, salah satu perbaikan yang dapat dilakukan untuk penyelengaraan selanjutnya adalah mengelompokkan peserta. Misalnya, kelas dengan peserta dari koperasi konvensional yang ingin berubah menjadi syariah dan kelas dengan peserta seluruhnya dari koperasi syariah sehingga kelas bisa menjadi lebih homogen. Hal ini sesuai dengan penelitian dari Utomo dan Tahupejory (2014), bahwa untuk mengakomodasi perbedaan tingkat pemahaman dari peserta 
pelatihan, dapat dilakukan pengelompokan sesuai dengan kemampuan awal peserta, agar kelas bisa lebih seragam. Dengan demikian peserta dagan tingkat pemaham rendah dan peserta dengan tingkat pemahaman tinggi mendapatkan manfaat besar yang sama dari pelatihan. Selain itu, penjenjangan pelatihan juga dapat didilakukan dengan membagi pelatihan dengan beberapa tingkat. Misalnya tingkat dasar, menengah dan mahir sehingga peserta bisa menjadi lebih homogen.

\section{KESIMPULAN}

Dari hasil evaluasi pelatihan penyusunan laporan keuangan syariah bagi pengurus koperasi mengunakan model evaluasi Kirkpatrik dapat disimpulkan bahwa evaluasi Kirkpatrik level 1 (reaksi) mengambarkan kepuasan (reaksi positif) dari peserta terhadap pelaksanaan pelatihan. Hal ini dapat dilihat dari beberapa aspek yang dinilai yaitu aspek materi, fasilitator, waktu pelaksanaan, konsumsi serta sarana dan prasarana yang mendapat penilaian baik dari peserta. Sedangkan dari evaluasi level 2 (pembelajaran), terjadi peningkatan pengetahuan tentang materi penyusunan laporan keuangan bagi koperasi. Peningkatan yang didapat bervariasi dengan rata-rata penambahan nilai 19,11 point. Adanya penambahan nilai post- test menunjukkan adanya peningkatan pengetahuan dan skill dari peserta pelatihan dan menunjukkan adanya proses pembelajaran yang efektif. Namun demikian, ada beberapa saran perbaikan yang dapat dilakukan oleh penyelenggara pelatihan maupun fasilitator agar program pelatihan ke depan dapat berjalan lebih baik. Adapun saran perbaikan tersebut yaitu, 1) fasilitator tetap perlu melakukan update kompetensi dan pengetahuan serta mengembangkan metode pembelajaran untuk meningkatkan kepuasan peserta pada proses pembelajaran di masa yang akan datang, 2) penyediaan sarana dan prasarana dapat lebih ditingkatkan seperti penyediaan tempat ibadah yang lebih representatif, 3) melakukan pengelompokan peserta sesuai dengan kemampuan awal peserta, agar kelas bisa lebih seragam atau dengan membuat pelatihan yang berjenjang. Untuk mengetahui efektifitas pelatihan secara keseluruhan, maka untuk penelitian selanjutnya, perlu dilakukan evaluasi level 3 (tingkah laku) dan evaluasi level 4 (hasil). Evaluasi level 3 yaitu untuk mengukur sejauh mana peserta menerapkan pemahaman kompetensi yang diperoleh dalam lingkungan pekerjaannya dan evaluasi level 4 yaitu untuk mengukur seberapa besar dampak pelaksanaan pelatihan terhadap kinerja pekerjaan ataupun hasil akhir yang diharapkan.

\section{DAFTAR PUSTAKA}

Aditama, R. A. (2020). Pengantar Manajemen. AE Publishing.

Arifin, Johar. (2009). Komputer Akuntansi Koperasi Simpan Pinjam dengan MS Exel. Jakarta. Elex Media Komputindo.

Aulia, R. (2020). Penerapan Model Evaluasi Kirkpatrick pada Pelatihan Dasar CPNS Calon Hakim MA pada Mata Pelatihan ANEKA di Balai Diklat Keagamaan Jakarta. Wawasan: Jurnal Kediklatan Balai Diklat Keagamaan Jakarta, 1(2), 22-29.

Aulia, T. Z. (2018). Pemahaman atas Laporan Keuangan Guna Ketepatan Waktu Pelaksanaan Rapat Anggota Tahunan (RAT) pada Koperasi di Kota Tangerang. In Prosiding Seminar Nasional Unimus (Vol. 1).

Badu, S. Q. (2012). Implementasi evaluasi model Kirkpatrick pada perkuliahan masalah nilai awal dan syarat batas. Jurnal Penelitian dan Evaluasi Pendidikan, 16, 102-129.

Basir, F. (2013). The Program Evaluation of Education and Training Leadership IV at Makassar Education and Training Religious Center Using Kirkpatrick Model. Jurnal Evaluasi Pendidikan, 4(2), 78704.

Kirkpatrick, D., \& Kirkpatrick, J. (2006). Evaluating training programs: The four levels. Berrett-Koehler Publishers.

Permenkop dan UKM RI 2015 No. 18, Pedoman Pendidikan dan Pelatihan Bagi Sumber Daya Manusia Koperasi, Pengusaha Mikro, Kecil, dan Menengah. 
Shodiq, M. (2021). Evaluasi Reaksi dan Pengetahuan Peserta Terhadap Mata Pelatihan Etika Publik. Manajerial: Jurnal Inovasi Manajemen dan Supervisi Pendidikan, 1(1), 2532.

Utomo, A. P., \& Tehupeiory, K. P. (2014). Evaluasi pelatihan dengan metode Kirkpatrick analysis. Jurnal Telematika, 9(2), 37. 